University of Nebraska - Lincoln

DigitalCommons@University of Nebraska - Lincoln

Roman L. Hruska U.S. Meat Animal Research

U.S. Department of Agriculture: Agricultural Center

Research Service, Lincoln, Nebraska

2013

\title{
The Plasminogen Activator System in the Ovine Placentome During Late Gestation and Stage-Two of Parturition
}

\author{
Anthony K. McNeel \\ USDA-ARS, anthony.mcneel@ars.usda.gov \\ Robert A. Cushman \\ USDA-ARS, Bob.Cushman@ars.usda.gov \\ Jeffrey L. Vallet \\ USDA-ARS
}

Follow this and additional works at: https://digitalcommons.unl.edu/hruskareports

McNeel, Anthony K.; Cushman, Robert A.; and Vallet, Jeffrey L., "The Plasminogen Activator System in the Ovine Placentome During Late Gestation and Stage-Two of Parturition" (2013). Roman L. Hruska U.S. Meat Animal Research Center. 213.

https://digitalcommons.unl.edu/hruskareports/213

This Article is brought to you for free and open access by the U.S. Department of Agriculture: Agricultural Research Service, Lincoln, Nebraska at DigitalCommons@University of Nebraska - Lincoln. It has been accepted for inclusion in Roman L. Hruska U.S. Meat Animal Research Center by an authorized administrator of DigitalCommons@University of Nebraska - Lincoln. 


\title{
The Plasminogen Activator System in the Ovine Placentome During Late Gestation and Stage-Two of Parturition
}

\author{
ANTHONY K. McNEEL, ${ }^{*}$ ROBERT A. CUSHMAN, AND JEFFREY L. VALLET \\ United States Department of Agriculture (USDA), Agricultural Research Service, U.S. Meat Animal Research Center, \\ Reproduction Research Unit, Clay Center, Nebraska
}

\section{SUMMARY}

The process of placental separation is not completely understood. In domestic animals, especially cattle, it is important that expulsion of the fetal membranes takes place in a timely manner in order to achieve maximal reproductive efficiency. The activity of the matrix-metalloprotease (MMP) family of proteases is known to be reduced in placentomes from cases of retained placenta. Members of the MMP family are known to be activated by the plasminogen activator (PA) family of proteases. We hypothesized that the expression and activity of the PA family increase in the cotyledon and/or caruncle as parturition approaches, with maximal expression and activity at parturition. To test this hypothesis, we performed reverse-transcriptase quantitative PCR and plasminogen-casein zymography to detect the presence and activity of PA family members in the placentome leading up to and during parturition in spontaneous and dexamethasone-induced parturient ewes. The results from our experiments indicated that serine proteases inhibitor E1 (SERPINE1) mRNA abundance in the cotyledon was different between treatment groups $(P=0.0002)$. In the caruncle, gene expression for plasminogen activator urokinase-type (PLAU) was different $(P=0.0154)$, and there was a strong trend for differences in SERPINE1 expression $(P=0.0565)$. These results demonstrate that expression of the PA system in the placentome changes from late pregnancy to parturition, and the presence or activity of these enzymes may occur after fetal expulsion.

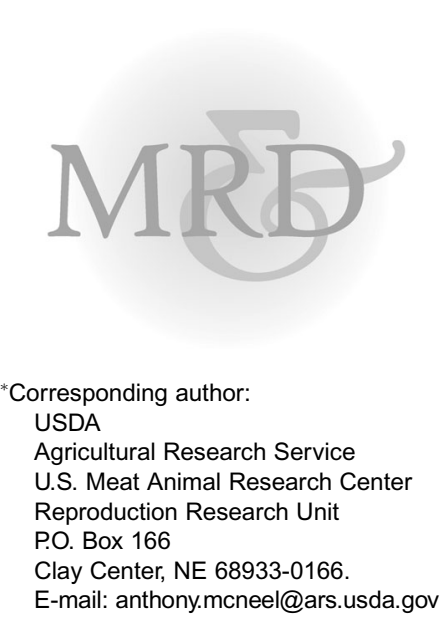

Mol. Reprod. Dev. 80:466-473, 2013. Published 2013 Wiley-Periodicals, Inc. ${ }^{\dagger}$

Disclaimer: Mention of trade names or commercial products in this publication is solely for the purpose of providing specific information and does not imply recommendation or endorsement by the U.S. Department of Agriculture.

The U.S. Department of Agriculture (USDA) prohibits discrimination in all its programs and activities on the basis of race, color, national origin, age, disability, and where applicable, sex, marital status, familial status, parental status, religion, sexual orientation, genetic information, political beliefs, reprisal, or because all or part of an individual's income is derived from any public assistance program. (Not all prohibited bases apply to all programs.) Persons with disabilities who require alternative means for communication of program information (Braille, large print, audiotape, etc.) should contact USDA's TARGET Center at (202) 720-2600 (voice and TDD). To file a complaint of discrimination, write to USDA, Director, Office of Civil Rights, 1400 Independence Avenue, S.W., Washington, D.C. 20250-9410, or call (800) 795-3272 (voice) or (202) 720-6382 (TDD). USDA is an equal opportunity provider and employer.

Abbreviations: MMP, matrix metalloprotease; PA, plasminogen activator; PLAT, plasminogen activator tissue-type; PLAU[R], plasminogen activator urokinase-type [receptor]; SERPIN, serine protease inhibitor 


\section{INTRODUCTION}

Retained placenta is a reproductive disorder of significant concern to dairy producers as it has recently been estimated to reduce milk production by $753 \mathrm{~kg}$ over the course of a 305-day lactation period (Dubuc et al., 2011). Aside from lost milk production, retained placenta increases the risk for developing endometritis; together, these reproductive disorders are associated with reduced pregnancy rates $(15 \%$ and $16 \%$, respectively; Fourichon et al., 2000). Both are associated with an increased risk of metritis (Dubuc et al., 2010), and extend days-to-conception by 7 days (Fourichon et al., 2000). Retained placenta is also of concern for beef producers as induction of parturition (e.g. with dexamethasone) or Cesarean sections are known to increase the risk of the same disorder (Eiler and Fecteau, 2007).

Placental development in ruminants is mediated by trophoblast adhesion mainly within the placentome. Adhesion of trophoblasts to endometrial cells occurs through the action of integrins and their interaction with extracellular matrix proteins, most notably osteopontin (Johnson et al., 2003). During parturition, integrin-mediated adhesion must be disrupted in order to facilitate proper expulsion of the fetal membranes, which is an important step for the proper involution of the uterus following pregnancy. Studies that have investigated the molecular mechanism of placentome separation are limited, and have primarily focused on the collagenolytic family of proteases. Gross et al. (1985) were the first to report reduced collagenolytic activity in cases of retained placenta, but subsequent studies have produced conflicting results in terms of whether or not collagenolytic activity is reduced (Maj and Kankofer, 1997; Walter and Boos, 2001; Dilly et al., 2011).

Collagenases, also known as matrix-metalloproteases (MMPs), are a family of $26 \mathrm{Zn}^{2+}$-dependent endoproteases. Four inhibitors (tissue inhibitor of matrix-metalloproteases: TIMPs) of these proteases are known to play roles in modulating the activities of the MMP. Each MMP possesses a spectrum of specificities for different extracellular matrix proteins with some functional overlap, the most common being collagen (Overall, 2002). MMPs are synthesized and secreted as inactive zymogens (proMMPs). Activation involves removal of the $\mathrm{N}$-terminus to expose the catalytic $\mathrm{Zn}^{2+}$, referred to as the cysteine switch (Chakraborti et al., 2003). Once pro-MMPs are secreted, it is thought that proteases within the plasminogen activator (PA) family are responsible for MMP activation (Ny et al., 2002; Curry and Osteen, 2003). The PA family consists of the enzymes plasmin/plasminogen (PLG), plasminogen activator tissue-type (PLAT), plasminogen activator urokinase-type (PLAU), and its receptor (PLAUR). Inhibitors of the PA family include $\alpha_{2}$-antiplasmin, plasminogen activator inhibitor-1 (SERPINE1), plasminogen activator inhibitor-2 (SERPINB2), and protein $\mathrm{C}$ inhibitor (SERPINA5). These inhibitors covalently bind to their ligands, blocking activity of the enzyme, and eventually leading to their degradation (Olson et al., 2001).
Plasminogen is proteolytically converted to plasmin by other proteases, most notably PLAT and PLAU (Ny et al., 2002). Both activators are also secreted as single polypeptide chains and possess little (PLAT) to no (PLAU) activity in their single chain form (Mayer, 1990). When exposed to fibrin (PLAT) or bound to their receptor (PLAU), these enzymes gain limited activity that is sufficient to initiate a reciprocal activation cascade with plasminogen/ plasmin (Lijnen et al., 1990; Higazi et al., 1995). PA-dependent activation of MMPs can result in the activation of proPA and other MMPs, further propagating the proteolytic cascade (Orgel et al., 1998; Ny et al., 2002; Xu et al., 2010). Under normal physiological conditions, the ratio between the PA enzymes and their inhibitors favors the inhibitors. The known role of PA in activation of MMPs, combined with reports that placentomes from retained fetal membranes possess reduced MMP activity, suggests that reduced PA activity may play a role in the pathogenesis of retained placenta in cattle. To elucidate the involvement of the PA system in placental separation and retained placenta, we compared PA expression and activity in placentomal tissues from late gestation, in spontaneously lambing ewes, and in ewes induced to lamb with dexamethasone. Lastly, as tissue collection technique is more invasive than a standard Cesarean section, we documented the impact of Cesarean section/placentome collection on subsequent reproductive performance.

\section{RESULTS}

\section{Reproductive Performance of Ewes Following Cesarean Section}

Neither the number of lambs nor the sex of the lambs in the litter were different between any of our treatments ( $P=0.44$ and $P=0.77$, respectively). None of the 13 ewes from which placentomes were collected at parturition died from the procedure, and no ewe experienced retained placenta. Of these, 12 ewes were mated via live cover, and 11 were subsequently found to be pregnant $(91.7 \%)$.

\section{Reverse Transcriptase Quantitative (Real-Time) PCR}

Messenger RNA abundance in the cotyledon for PLAU, $P L A U R$, and SERPINB2 was not different for any treatment group $(P>0.05$, Fig. $1 \mathrm{~A}, \mathrm{~B}, \mathrm{D})$. There was a treatment effect on mRNA abundance for SERPINE1 $(P=0.0002)$ in cotyledonary tissue, however. Abundance of SERPINE1 mRNA in cotyledonary tissues was greatest in those ewes treated with $10 \mathrm{mg}$ of dexamethasone compared to all other treatment groups (Fig. 1C).

In the caruncle, there were no treatment effects on mRNA abundance of PLAUR or SERPINB2 $(P>0.05$; Fig. 2B,D), but there was a treatment effect on mRNA abundance of PLAU $(P=0.015)$ and a strong tendency for SERPINE1 ( $P=0.0565)$. Lastly, neither PLAT nor PLG expression could be detected using multiple sets of primers at different locations along the transcript. 

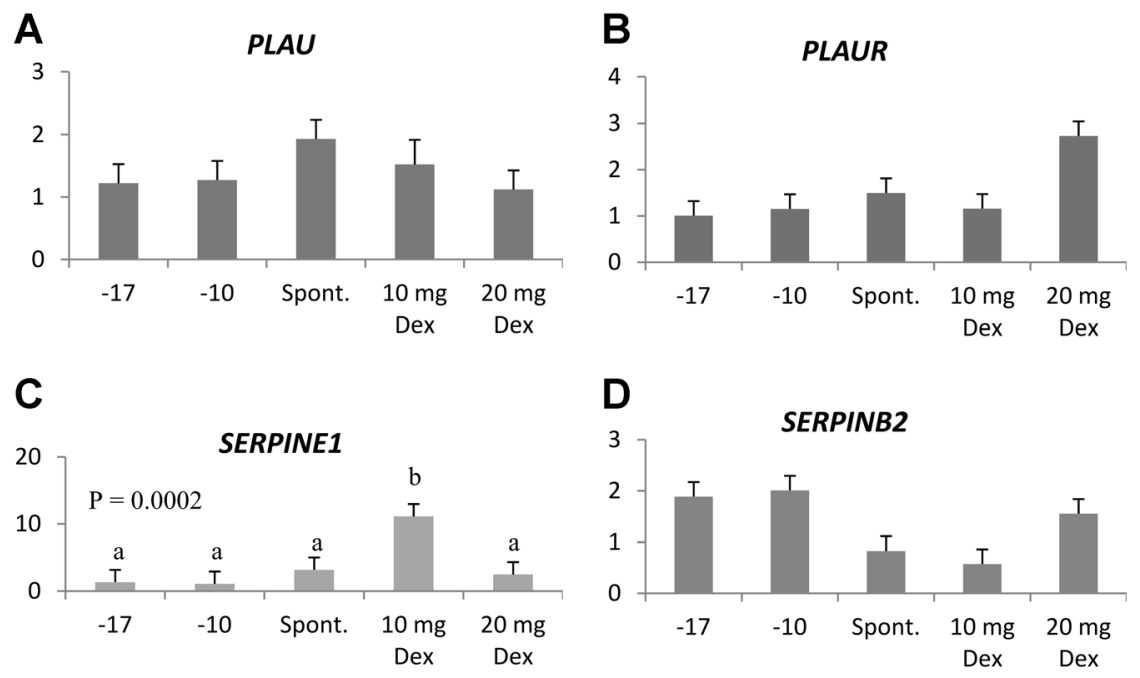

E

$\mathbf{F}$
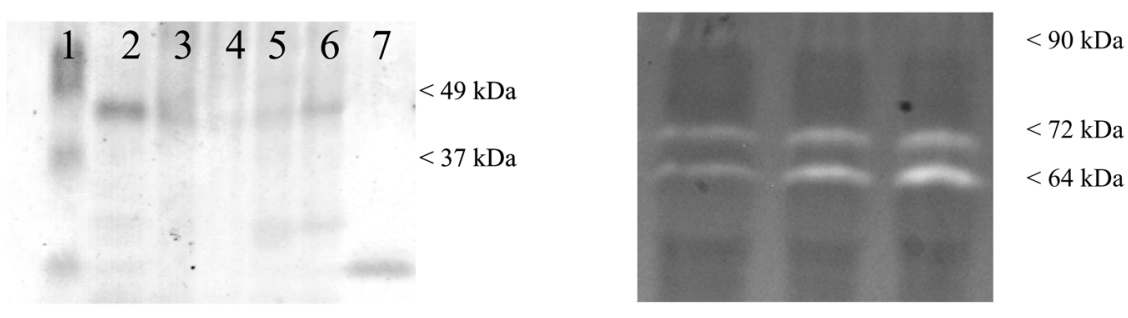

Figure 1. A-E: Least-squares means of the relative mRNA abundance for genes of interest in cotyledonary tissue from ewes collected 17 days before predicted parturition $(-17 \mathrm{~d} ; n=5) ; 10$ days before predicted parturition ( $-10 \mathrm{~d} ; \mathrm{n}=5$ ); at spontaneous parturition (Spont.; $\mathrm{n}=5$ ); and from ewes induced to lamb with $10 \mathrm{mg}$ (10 mg Dex; $\mathrm{n}=3)$ and $20 \mathrm{mg}(20 \mathrm{mg} \mathrm{Dex} ; \mathrm{n}=5)$ dexamethasone. Groups with different superscripts are significantly different $(P<0.05)$. F: Representative immunoblot of $80 \mu \mathrm{g}$ of protein from homogenates of ovine cotyledons with anti-PLAU-specific goat IgG (Lane 1: pre-stained ladder; Lanes 2-6: cotyledonary tissue extracts; Lanes 7: human PLAU). Band at $\sim 48 \mathrm{kDa}$ is presumed to be ovine IgG, as exclusion of a primary antibody also resulted in staining at this molecular weight. G: Representative gelatin zymograph for gelatinase activity in $80 \mu \mathrm{g}$ of protein from cotyledon homogenates.

\section{Immunoblotting and Casein-Plasminogen Zymography}

Plasminogen casein zymography failed to detect PA activity in cotyledons and caruncles at all time points (data not shown), even though purified human PLAU activity was detectable at $24 \mathrm{hr}$ of incubation to levels as low as $25 \mathrm{mIU}$. Using immunoblotting, only the positive control (50 IU purified human urokinase-type PA) was detected. Gelatin zymography (as described by Maj and Kankofer, 1997) of a selected number of cotyledonary and caruncular tissue samples indicated that the samples do possess gelatinolytic capacity, indicating that the samples were not compromised during tissue collection or extraction (data not shown).

\section{DISCUSSION}

While we found no differences in expression for PLAU, PLAUR, and SERPINB2 in the cotyledon at any time point or treatment examined, differences in mRNA abundance of SERPINE1 were observed. Serine protease inhibitor E1 (also called plasminogen activator inhibitor-1, or PAI-1) along with SERPINB2 (PAI-2), are the main inhibitors of PAs (Blasi et al., 1987; Conese and Blasi, 1995). Elevated expression of SERPINE1 during parturition is to be expected, as it is known to be regulated by dexamethasone in vivo (Medcalf et al., 1988) and circulating concentrations of glucocorticoids are elevated during parturition. Aside from its ability to bind to and ablate PA activity, SERPINE1 is also capable of regulating cell adhesion to the extracellular matrix by obscuring the RGD integrin recognition tripeptide found within vitronectin (Deng et al., 2001). Localized secretion of SERPINE1 to the fetal-maternal interface would disrupt adhesion of the cotyledon to the caruncle, which would mediate placental separation/expulsion. While vitronectin does not appear to be distributed along the fetal x2013;maternal interface (Burghardt et al., 2009), osteopontin is present, though it is unknown if a similar 

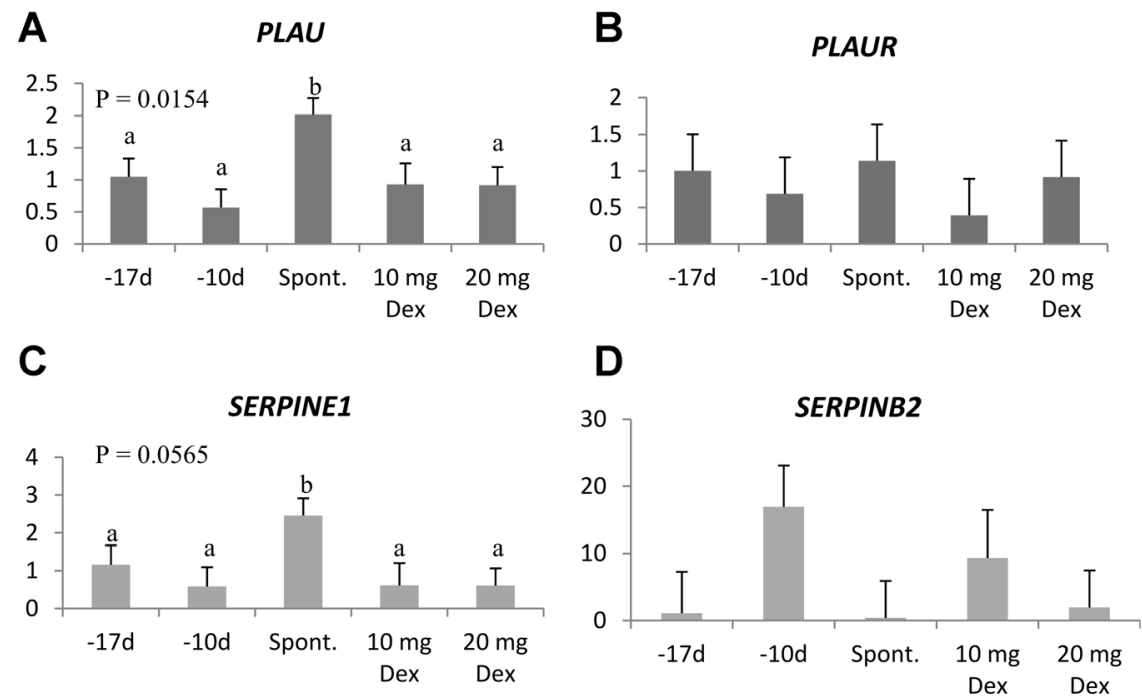

E

$\mathbf{F}$
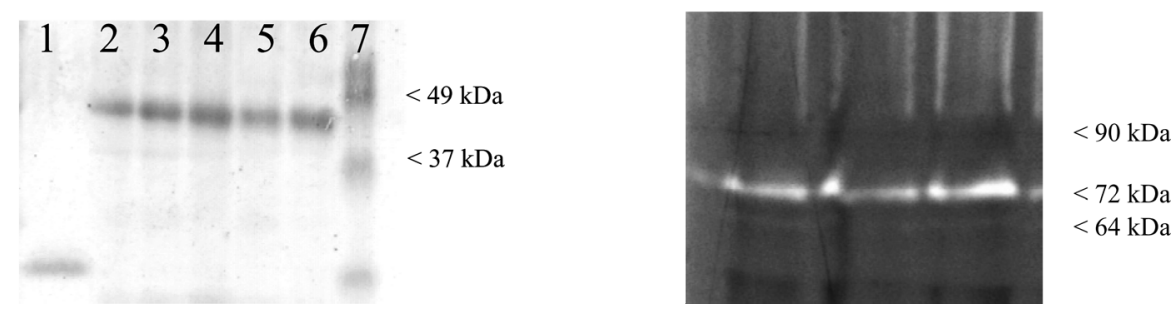

\begin{abstract}
Figure 2. A-E: Least-squares means of the relative mRNA abundance for genes of interest in caruncular tissue from ewes collected 17 days before predicted parturition $(-17 \mathrm{~d} ; n=4) ; 10$ days before predicted parturition $(-10 \mathrm{~d} ; n=4)$; at spontaneous parturition (Spont.; $n=5)$; and from ewes induced to lamb with $10 \mathrm{mg}(10 \mathrm{mg} \mathrm{Dex} ; \mathrm{n}=3)$ and $20 \mathrm{mg}(20 \mathrm{mg}$ dex; $\mathrm{n}=5)$ dexamethasone. Groups with different superscripts are significantly different $(P<0.05)$. F: Representative immunoblot of $80 \mu \mathrm{g}$ of protein from homogenates of ovine cotyledons stained with anti-PLAU-specific goat IgG (Lane 1: human PLAU; Lanes 2-6: caruncular tissue extracts; Lane 7: pre-stained ladder). No specific binding for PLAU was observed in either tissue. Band at $\sim 48 \mathrm{kDa}$ is presumed to be ovine $\mathrm{lgG}$, as exclusion of a primary antibody also resulted in staining at this molecular weight. G: Representative gelatin zymograph for gelatinase activity in $80 \mu \mathrm{g}$ of protein from caruncle homogenates.
\end{abstract}

interaction takes place between osteopontin and SERPINE1. Further work investigating the distribution of SERPINE1 in the placentome and its ability to bind to osteopontin is needed to clarify its role in placental separation in ruminants.

Differences in PLAU mRNA abundance in the caruncle may reflect the anticipation of placental separation, increased leukocyte prevalence within the placentome, and/or extracellular matrix remodeling as part of uterine involution following parturition. While PLAU mRNA expression was detected using reverse transcriptase quantitative PCR, PLAU was not detected by immunoblotting or plasminogen-casein zymography. It is unlikely that our samples contain meaningful PLAU activity as we were able to routinely detect the positive control down to $25 \mathrm{mIU}$ (9.25 ng) of human PLAU, and overloading of samples in the zymograph (up to $360 \mu \mathrm{g}$ of protein) also failed to detect PLAU activity at any time point. The antibody used for immuno- blotting has been previously demonstrated to recognize active sheep PLAU (Colgin and Murdoch, 1997). Thus, this discrepancy between the presence of PLAU mRNA and PLAU protein suggests that there are additional factors controlling translation of the transcript into protein. MicroRNAs are known to repress both translation and increase mRNA decay (Huntzinger and Izaurralde, 2001). Additionally, the number of ribosomes associated with a transcript has been shown to influence the abundance of a protein (Van Der Kelen et al., 2009). Additional experiments utilizing serial collections of placentomes over the course of stage-three of parturition are needed to elucidate what mechanisms are responsible for impaired translation of PLAU. To that end, we have recently developed an inexpensive instrument and methodology to make these collections transvaginally in cattle (McNeel et al., 2013).

We were unable to detect PA and plasmin activity at any time point or treatment examined. Our protein data support 
observations by other investigators, who noted a lack of differences in fibrinolysis or caseinolysis in whole tissue minces (Gross et al., 1985). While these authors failed to detect differences in fibrinolysis (e.g., plasmin activity in whole placentomes), this is not the only avenue by which the PA system can activate MMPs as PLAU is known to directly cleave MMP-9 (Zhao et al., 2008). The presence of MMP activity in the samples indicates that proteolytic activity of the samples had not been compromised during tissue collection or protein extraction.

Our observations of the PA system suggest that if transcription of the entire PA system changes between late gestation and parturition, as observed by other investigators (Streyl et al., 2012), these changes depend on the fetus traversing the birth canal. An endocrine signal(s) has been recently proposed for such an event (Kamada et al., 2012), which appear to be secreted after fetal expulsion; this lag may account for the variation in time between expulsion of the calf and expulsion of the placenta. Differences between our data and that from other investigators (Streyl et al., 2012) may be due to differences in timing of tissue collection, in cDNA preparation (oligo-dT vs. oligo-dT and random decamers), in the mechanisms responsible for placental separation between cattle and sheep, or in method of assessment (e.g., inherent differences between microarray and reverse transcriptase quantitative PCR).

While cattle and sheep share identical placental microanatomy, these species differ in their placentomal gross morphology. In the ewe, the caruncle encapsulates the cotyledon whereas the cotyledon encapsulates the caruncle in the bovine. Furthermore, it is known that the morphological features of adjacent placentomes from sheep and cattle differ during the last trimester (Rici et al., 2011). In sheep, single placentomes are distinct during the last third of gestation, while in cattle it appears that there is some degree of fusion between multiple adjacent placentomes. This fusion appears to be exclusively of fetal origin, as adjacent caruncles are distinctly separate (Rici et al., 2011). The impact that these differences in placentomal morphology might have on the mechanisms of placentomal separation is unknown.

In conclusion, our data demonstrate that differences in expression of PA system components during late gestation and stage-two of parturition in the ovine placentome are of fetal and maternal origin, but neither PLAU protein nor activity can be detected using Western blotting or plasminogen-casein zymography. Based on changes in gene expression within the PA system between late gestation and parturition, the molecular mechanisms regulating separation of the placentome in the ewe appear to follow a different time course than cattle.

\section{MATERIALS AND METHODS}

\section{Animals}

All procedures were approved by the U.S. Meat Animal Research Center (USMARC) Institutional Animal Care and
Use Committee, and were in accordance with Federation for Animal Science Society (FASS) guidelines for the use of agricultural animals in research. Placentomes were collected from 23 pregnant ewes at the following five different time points: at 17 days prior to parturition ( -17 days; $n=5)$; at 10 days prior to parturition ( -10 days; $n=5)$; at spontaneous parturition ( 0 days; $n=5$ ); at induced parturition using $10 \mathrm{mg}$ dexamethasone (10Dex; $\mathrm{n}=3$ ); and at induced parturition using $20 \mathrm{mg}$ dexamethasone (20Dex; $\mathrm{n}=5$ ). Ewes induced to lamb were treated with dexamethasone $48 \mathrm{hr}$ prior to their projected lambing date, which was calculated using recorded grease harness marking records and average gestational length of the flock from previous lambing seasons.

Ewes at 17 and 10 days prior to parturition were sacrificed at the USMARC abattoir after stunning with a captive bolt followed by exsanguination. The reproductive tract was removed from the ewe, and an incision was made along the anti-mesometrial side of the uterus to expose the fetus and associated fetal membranes. A single, intact representative placentome was excised, excess fetal membranes and endometrium were trimmed, the placentome was separated into cotyledonary and caruncular components, placed into $2.0 \mathrm{ml}$ cryovials, and snap frozen in liquid nitrogen within 15 min of stunning. Samples were stored at $-80^{\circ} \mathrm{C}$ until RNA and protein extraction.

Ewes spontaneously lambing and those induced to lamb with dexamethazone were observed for signs of parturition (e.g. protrusion of the chorioallantoic membrane from the vulva). Within $30 \mathrm{~min}$ of the rupture of the fetal membranes, a line block using $30 \mathrm{ml}$ of $2 \%$ lidocaine injected subcutaneously was performed, an incision for a Cesarean section was made, any remaining lambs were removed, and the endometrium was exposed. A single representative placentome was then selected, clamped at the base of the caruncle, and excised using a scalpel. Harvested tissues were handled and stored as described in the previous section. Following tissue collection, normal Cesarean section procedures for closing the uterus, muscle layer, and skin were performed. Animals were provided with flunixin meglumine IV (50 mg/45 kg), penicillin G IM (300 kIU/ml at $1.05 \mathrm{MIU} / 45 \mathrm{~kg}$ of BW), and $40 \mathrm{IU}$ oxytocin immediately following the procedure. For the $48 \mathrm{hr}$ following surgery, ewes were treated daily with penicillin G IM $(150 \mathrm{k} \mathrm{IU} / \mathrm{ml}$ at $450 \mathrm{k} \mathrm{IU} / 45 \mathrm{~kg}$ of BW), followed by $1.5 \mathrm{ml}$ of penicillin $\mathrm{G}$ and benzathine IM (150 k IU/ml each at $1.5 \mathrm{ml} / 45 \mathrm{~kg})$. All ewes expelled their fetal membranes within $24 \mathrm{hr}$ of the procedure. Ewes and lambs were then returned to the flock to continue the production cycle. Six months later, ewes were pasture-bred and checked for pregnancy via ultrasonography 60 days following removal of the rams.

\section{RNA Extraction and Quantification}

Cotyledonary and caruncular tissues were homogenized, and RNA was extracted using TRIzol (Invitrogen, Carlsbad, CA) according to manufacturer's instructions. Purified RNA was suspended in autoclaved distilled water and quantified on a Nanodrop 1000 (Thermoscientific, 
TABLE 1. Primers Used to Determine Relative Quantification of mRNA Expression Using RT-qPCR

\begin{tabular}{|c|c|c|c|c|c|}
\hline Gene & Forward & Reverse & Amplicon size & $\mathrm{T}_{\mathrm{m}}$ & Ref. accession \# \\
\hline $\begin{array}{l}\text { PLAU } \\
\text { PLAUR } \\
\text { SERPINE1 } \\
\text { SERPINB2 } \\
\text { GAPDH }\end{array}$ & $\begin{array}{l}\text { 5'-ACCATCTGCCTGCCCCCACT } \\
\text { 5'-AGCGCCCACAGGTGTTCCTC } \\
\text { 5'-GGTCCGCGGTTTCATGCCCA } \\
\text { 5'-GGGCGCCCGGGGAAATACTG } \\
\text { 5'-CCACCAACTGCTTGGCCCCC }\end{array}$ & $\begin{array}{l}\text { 5'-GGGTCAGCCGCACACAGCAT } \\
\text { 5'-CCCTTGCGGGGCTGGGCGTC } \\
\text { 5'-TACCAGGACCAGGCGCGTCA } \\
\text { 5'-GGACGCGTTGATGGCGTTGC } \\
\text { 5'-GGGATGACCTTGCCCACGGC }\end{array}$ & $\begin{array}{l}206 \mathrm{bp} \\
248 \mathrm{bp} \\
184 \mathrm{bp} \\
220 \mathrm{bp} \\
208 \mathrm{bp}\end{array}$ & $\begin{array}{l}60^{\circ} \mathrm{C} \\
58^{\circ} \mathrm{C} \\
59^{\circ} \mathrm{C} \\
59^{\circ} \mathrm{C} \\
60^{\circ} \mathrm{C}\end{array}$ & $\begin{array}{l}254692795 \\
254692821 \\
291621639 \\
290795367 \\
296785214\end{array}$ \\
\hline
\end{tabular}

Wilmington, DE). Only samples with a $280 / 260$ absorbance greater than 1.7 were used for reverse transcription.

\section{Reverse Transcription and Primer Design}

One microgram of RNA was reverse transcribed using the Superscript III kit (Invitrogen), according to manufacturer's instructions, and cDNA was diluted to $100 \mu \mathrm{l}$ with autoclaved distilled water. Primers for quantitative PCR (Table 1) were designed using PRIMER-BLAST (Rozen and Skaletsky, 2000) with ovine sequences when available (PLAU, PLAUR, SERPINE1, SERPINB2, GAPDH). Otherwise, alignments of the mouse, rat, human, and bovine sequences were used to search for regions of high homology, with the preference given to the bovine sequence (PLG, PLAT, SERPINA5). Intron-spanning primer pairs were chosen based on the annotation of the gene of interest in the bovine genome (Btau 4.6.1).

\section{Relative mRNA Expression Using Quantitative PCR}

Relative gene expression was conducted using Platinum Taq SYBR Green with UDG (Invitrogen), according to manufacturer's instructions. Briefly, $1.0 \mu \mathrm{l}$ of cDNA was combined with $19 \mu \mathrm{l}$ of a master mix containing $200 \mathrm{nM}$ of each primer, $10 \mu \mathrm{l}$ Platinum Taq master mix $(400 \mu \mathrm{M}$ dATP, dCTP, dGTP, $800 \mu \mathrm{M}$ TTP, $6 \mathrm{mM} \mathrm{MgCl}$, Hot-Start Platinum Taq) and autoclaved distilled water. Polymerase chain reactions were subjected to 40 cycles of the following: $95^{\circ} \mathrm{C}$ for $10 \mathrm{sec}$; $30 \mathrm{sec}$ at an annealing temperature indicated in Table $1 ; 10 \mathrm{sec}$ at $72^{\circ} \mathrm{C}$. Reactions were conducted in a 96-well plate on a Roche Light Cycler 480 (Roche Applied Science, Indianapolis, IN). Negative controls for each primer pair consistently failed to generate signal. Primer pairs generated a single peak during melting curve analysis, and visualization of the PCR products by $2 \%$ gel electrophoresis produced a single band at the predicted size. Gene expression was calculated using the $2^{-\Delta \Delta C_{t}}$ method (Livak and Schmittgen, 2001) with GAPDH serving as the reference gene and day -17 serving as the reference group.

\section{Protein Extraction and Quantification}

Protein was extracted from cotyledonary and caruncular tissues as described previously (Dow et al., 2002). Briefly, one-quarter of a cotyledon or caruncle was weighed and homogenized in the appropriate amount of extraction buffer
(1 $\mathrm{ml} / 500 \mathrm{mg}$ ) with a tissue homogenizer, then centrifuged at $9,000 \mathrm{~g}$ for $30 \mathrm{~min}$ at $4^{\circ} \mathrm{C}$. The supernatant was removed and stored at $-20^{\circ} \mathrm{C}$ for later assay. Protein samples were subjected to a maximum of three freeze-thaw cycles in order to reduce variation in enzyme activity. Protein concentrations were measured using the Pierce BCA kit (Thermoscientific) in a microplate, and read at $550 \mathrm{~nm}$ on a ElX $_{808}{ }^{\text {IU }}$ ultra microplate reader (Biotek instruments, Inc., Winooski, VT).

\section{Casein-Plasminogen Zymography}

Casein-plasminogen zymography was performed as described previously (Dow et al., 2002). Briefly, $80 \mu \mathrm{g}$ of protein from caruncle or cotyledon and a standard curve of high molecular weight human PLAU (American Diagnostica, Stamford, CT) were loaded onto castellated $4 \%$ polyacrylamide gels (0.375 M Tris, $0.1 \%$ SDS, $\mathrm{pH} 8.6)$ cast on top of a $10 \%$ polyacrylamide gels $(0.375 \mathrm{M}$ Tris, $0.1 \%$ SDS, pH 8.6) containing $0.025 \%$ hammerstein-casein (Sigma-Aldrich, St. Louis, MO) and $25 \mathrm{mU} / \mathrm{ml}$ bovine plasminogen (Sigma-Aldrich). Samples were electrophoresed for $1 \mathrm{hr}$ at $140 \mathrm{~V}$ in a Mini-Protean Tetra-cell (Bio-Rad, Hercules, CA). Gels were removed from the apparatus, the stacking gel was removed, and the running gel was washed in fresh $2.5 \%$ Triton X-100 for 45 min to remove SDS. Gels were then washed once in incubation buffer (50 mM Tris, $100 \mathrm{mM} \mathrm{NaCl}, \mathrm{pH}$ 7.6), placed in fresh incubation buffer, and incubated for $17 \mathrm{hr}$ at $37^{\circ} \mathrm{C}$. Gels were then washed once in water, placed in staining solution $(40 \%$ methanol, $40 \%$ distilled $\mathrm{H}_{2} \mathrm{O}, 10 \%$ acetic acid, $0.025 \%$ Coomassie Brilliant Blue) for $45 \mathrm{~min}$, and destained in staining solution without Coomassie. MMP-mediated caseinolysis is unlikely with this assay as both the electrophoresis and incubation buffers lack the metal ions $\left(\mathrm{Zn}^{2+}\right.$, $\mathrm{Ca}^{2+}$ ) necessary for MMP activity.

\section{Immunoblotting}

Eighty micrograms of cotyledonary or caruncular protein and 10 IU of active, high molecular weight PLAU (American Diagnostica) were subjected to SDS-PAGE as described previously (Buhi et al., 1989), with slight modifications. Gels were blotted onto nylon-supported nitrocellulose, then blocked in $50 \mathrm{mM}$ Tris, $1 \%$ Triton $\mathrm{X}-100$, and $1 \mathrm{M}$ $\mathrm{NaCl}, \mathrm{pH}$ 8.0. Membranes were incubated overnight with polyclonal goat anti-PLAU (American Diagnostica) with known cross-reactivity for ovine PLAU (Colgin and Murdoch, 1997) (1:1,000 dilution in blocking buffer). The 
next day, membranes were removed from the primary antibody, washed five times, and incubated in secondary rabbit anti-goat IgG conjugated to horseradish peroxidase (Sigma-Aldrich) (1:10,000 dilution) for $1 \mathrm{hr}$, and washed five times in blocking buffer and once in $0.9 \% \mathrm{NaCl}$. Membranes were then stained with NovaRed (Vector Labs, Burlingame, CA) according to kit instructions, using a tenfold dilution of detection substrate. Membranes were scanned using a Canon MX880.

\section{Statistical Analysis}

Relative gene expression was analyzed using the MIXED procedure of SAS version 9.2 (SAS Institute, Inc., Cary, NC), with treatment as the main effect. Differences were considered significant when $P \leq 0.05$.

\section{ACKNOWLEDGMENTS}

The authors thank the staff of USMARC sheep operations and abattoir, and the veterinary staff and students at the University of Nebraska Great Plains Veterinary Educational Center for their assistance with collecting tissues and subsequent post-operative care of the animals.

\section{REFERENCES}

Blasi F, Vassalli J-D, Danø K. 1987. Urokinase-type plasminogen activator: Proenzyme, receptor, and inhibitors. J Cell Biol 104:801-804.

Buhi WC, Vallet JL, Bazer FW. 1989. De novo synthesis and release of polypeptides from cyclic and early pregnant porcine oviductal tissue in explant culture. J Exp Zool 252:79-88.

Burghardt RC, Burghardt JR, Taylor JD II, Reeder AT, Nguen BT, Spencer TE, Bayless KJ, Johnson GA. 2009. Enhanced focal adhesion assembly reflects increased mechanosensation and mechanotransduction at maternal-conceptus interface and uterine wall during ovine pregnancy. Reproduction 137:567-582.

Chakraborti S, Mandal M, Das S, Mandal A, Chakraborti T. 2003. Regulation of matrix metalloproteinases: An overview. Mol Cell Biochem 253:269-285.

Colgin DC, Murdoch WJ. 1997. Evidence for a role of the ovarian surface epithelium in the ovulatory mechanism of the sheep: Secretion of urokinase-type plasminogen activator. Anim Reprod Sci 47:197-204.

Conese M, Blasi F. 1995. Urokinase/urokinase receptor system: Internalization/degradation of urokinase-serpin complexes: Mechanism and regulation. Biol Chem Hoppe Seyler 376: 143-155.

Curry TE, Jr., Osteen KG. 2003. The matrix metalloproteinase system: Changes, regulation, and impact throughout the ovarian and uterine reproductive cycle. Endocr Rev 24: 428-465.
Deng G, Curriden SA, Hu G, Czekay R-P, Loskutoff DJ. 2001. Plasminogen activator inhibitor-1 regulates cell adhesion by binding to the somatomedin B domain of vitronectin. $\mathrm{J}$ Cell Physiol 189:23-33.

Dilly M, Hambruch N, Shenavai S, Schuler G, Froehlich R, Haeger J-D, Ozalp GR, Pfarrer C. 2011. Expression of matrix metalloproteinase (MMP)-2, MMP-14 and tissue inhibitor of matrix metalloproteinase (TIMP)-2 during bovine placentation and at term with or without placental retention. Theriogenology 75:1104-1114.

Dow MPD, Bakke LJ, Cassar CA, Peters MW, Pursley JR, Smith GW. 2002. Gonadotropin surge-induced up-regulation of the plasminogen activators (tissue plasminogen activator and urokinase plasminogen activator) and the urokinase plasminogen activator receptor within bovine periovulatory follicular and luteal tissue. Biol Reprod 66:1413-1421.

Dubuc J, Duffield TF, Leslie KE, Walton JS, LeBlanc SJ. 2010. Risk factors for postpartum uterine diseases in dairy cows. J Dairy Sci 93:5764-5771.

Dubuc J, Duffield TF, Leslie KE, Walton JS, LeBlanc SJ. 2011. Effects of postpartum uterine diseases on milk production and culling in dairy cows. J Dairy Sci 94:1339-1346.

Eiler H, Fecteau KA. 2007. Retained placenta. In: Youngquist RS, Threlfall WR, editors. Current Therapy in large animal theriogenology, 2nd edition. St. Louis, MO: Saunders Elsevier. pp 345-354.

Fourichon C, Seegers H, Malher X. 2000. Effect of disease on reproduction in the dairy cow: A meta-analysis. Theriogenology 53:1729-1759.

Gross TS, Williams WF, Manspeaker JE, Russek E. 1985. In vitro proteolytic activity of the late pregnant and peripartum bovine placenta. J Anim Sci 61:391 (Abstract \# 448).

Higazi AA-R, Cohen RL, Henkin J, Kniss D, Schwartz BS, Cines DB. 1995. Enhancement of the enzymatic activity of single-chain urokinase plasminogen activator by soluble urokinase receptor. J Biol Chem 270:17375-17380.

Huntzinger E, Izaurralde E. 2001. Gene silencing by microRNAs: Contributions of translational repression and mRNA decay. Nat Rev Genet 12:99-110.

Johnson GA, Burghardt RC, Bazer FW, Spencer TE. 2003. Osteopontin: Roles in implantation and placentation. Biol Reprod 69:1458-1471.

Kamada H, Matsui Y, Sakurai Y, Tanigawa T, Itoh M, Kawamoto S, Kai K, Sasaki T, Takahashi K, Hayashi M, Takayama Y, Nakamura M, Kadokawa H, Ueda Y, Sutoh M, Murai M. 2012. Twelve oxo-eicosatetraenoic acid induces fetal membrane release after delivery in cows. Placenta 33:106-113.

Lijnen HR, Van Hoef B, De Cock F, Collen D. 1990. Effect of fibrinlike stimulators on the activation of plasminogen by tissue-type plasminogen activator (t-PA)---Studies with active site mutagenized plasminogen and plasmin resistant t-PA. Thromb Haemost 64:61-68. 
Livak KJ, Schmittgen TD. 2001. Analysis of relative gene expression data using real-time quantitative PCR and the 2 (-Delta Delta C(T)) Method. Methods 25:402-408.

Maj JG, Kankofer M. 1997. Activity of 72-kDa and 92-kDa matrix metalloproteinases in placental tissues of cows with and without retained fetal membranes. Placenta 18:683687.

Mayer M. 1990. Biochemical and biological aspects of the plasminogen activation system. Clin Biochem 23:197211.

McNeel AK, Ondrak JD, Cushman RA. 2013. Technical report: Serial collections of placentomes during parturition in cattle and subsequent reproductive performance. J Anim Sci (in press). doi: $10.2527 /$ jas.2012-5876

Medcalf RL, Van den Berg E, Schleuning W-D. 1988. Glucocorticoid-modulated gene expression of tissue- and urinary-type plasminogen activator and plasminogen activator inhibitor 1 and 2. J Cell Biol 106:971-978.

Ny T, Wahlberg P, Brändström IJM. 2002. Matrix remodeling in the ovary: Regulation and functional role of the plasminogen activator and matrix metalloproteinase systems. Mol Cell Endocrinol 187:29-38.

Olson ST, Swanson R, Day D, Verhamme I, Kvassman J, Shore JD. 2001. Resolution of Michaelis complex, acylation, and conformational change steps in the reactions of the serpin, plasminogen activator inhibitor-1, with tissue plasminogen activator and trypsin. Biochemistry 40:11742-11756.

Orgel D, Schröder W, Hecker-Kia A, Weithmann KU, Kolkenbrock $\mathrm{H}$, Ulbrich N. 1998. The cleavage of pro-urokinase type plasminogen activator by stromelysin-1. Clin Chem Lab Med 36:697-702.
Overall CM. 2002. Molecular determinants of metalloproteinase substrate specificity. Matrix metalloproteinase substrate binding domains, modules, and exosites. Mol Biotechnol 22:51-86.

Rici REG, Facciotti PR, Maria DA, Fernandes VM, Ambrosio CE, Miglino MA. 2011. Evaluation of the contribution of the placentomal fusion during gestation in cattle. Anim Reprod Sci 126: $143-150$

Rozen S, Skaletsky H. 2000. Primer3 on the WWW for general users and for biologist programmers. Methods Mol Biol 132: $365-386$.

Streyl D, Kenngott R, Herbach N, Wanke R, Blum H, Sinowatz F, Wolf E, Zerbe H, Bauersachs S. 2012. Gene expression profiling of bovine peripartal placentomes: Detection of molecular pathways potentially involved in the release of foetal membranes. Reproduction 143:85-105.

Van Der Kelen K, Beyaert R, Inzé D, De Veylder L. 2009. Translational control of eukaryotic gene expression. Crit Rev Biochem Mol Biol 44:143-168.

Walter I, Boos A. 2001. Matrix metalloproteinases (MMP-2 and MMP-9) and tissue inhibitor-2 of matrix metalloproteinases (TIMP-2) in the placenta and interplacental uterine wall in normal cows and in cattle with retention of fetal membranes. Placenta 22:473-483.

Xu D, McKee CM, Cao Y, Ding Y, Kessler BM, Muschel RJ. 2010. Matrix metalloproteinase-9 regulates tumor cell invasion through cleavage of protease nexin-1. Cancer Res 70: 6988-6998.

Zhao Y, Lyons CE, Jr., Xiao A, Templeton DJ, Sang QA, Brew K, Hussaini IM. 2008. Urokinase directly activates matrix metalloproteinases-9: A potential role in glioblastoma invasion. Biochem Biophys Res Commun 369:1215-1220. 